\title{
EDITORIAL
}

\section{La Revista Chilena de Radiología y las Estrategias para el Futuro}

La Revista Chilena de Radiología es el medio de difusión de la actividad científica de nuestra especialidad. Además de la calidad de sus artículos y de la visibilidad que se ha logrado en estos años, mantiene un enfoque dirigido a radiólogos generales y se suma a los pocos medios de información científica en español en el área de las imágenes médicas.

¿Es necesario introducir cambios o mejoras en este período, entonces? Un hombre entusiasta y vigoroso fue contratado como leñador, a cargo de talar un bosque mientras su supervisor estaba de viaje. El primer día logra derribar 15 árboles; trabaja todavía con más ganas el segundo día pero sólo consigue cortar 12; no conforme con su trabajo se levanta más temprano el tercer día haciendo caer 10; frustrado ya, había cortado sólo 6 al cuarto día cuando vuelve el supervisor. Desilusionado, le cuenta su experiencia; su jefe entonces pregunta "¿Y cuánto tiempo dedicaste a afilar el hacha"?

La calidad no es una meta, es un proyecto de mejoramiento continuo. Es así como nos encontramos trabajando en estrategias para mejorar la publicación de trabajos originales, especialmente aquellos presentados en el Congreso Chileno de Radiología. Respecto del proceso editorial, podemos dar cuenta de dos grandes avances. El primero es el establecimiento de un nuevo comité editorial, más numeroso, con participación activa de colegas de regiones y que cuenta con la incorporación de profesionales de las áreas de Medicina Nuclear y Tecnología Médica, cuyo trabajo ha estado siempre íntimamente ligado a nuestra especialidad.

El segundo avance, es la firma de un contrato con la empresa editorial Elsevier España para la asesoría en la calidad técnica de nuestras publicaciones, en el diseño de la revista y en la puesta en marcha de una página web para la publicación en línea. Este contrato incluye para nosotros además la puesta en marcha del sistema editorial de Elsevier, la maquetación utilizando el formato estándar de Elsevier, la incorporación de la revista en el sistema de ahead of print, la publicación electrónica en Elsevier y Science-Direct y la inclusión de nuestros artículos en Scopus, a contar del segundo semestre.

Con la profesionalización de nuestro trabajo editorial, aumentar el número y calidad de nuestros trabajos científicos publicados son las metas concretas del trabajo de nuestro nuevo comité editorial. Serán de especial interés en este plan los artículos originales y los artículos de revisión, estos últimos, los más descargados en el portal Scielo según nuestra reciente evaluación.

Sin duda los desafíos planteados por este plan son enormes y superan con creces los logros que pudieran alcanzar individualmente el comité o la editorial. Es una oportunidad para registrar y mostrar lo que estamos haciendo, lo que nos distingue o nos gusta. La ventana está abierta.

Dr. Marcelo Gálvez M.

Editor Científico Revista Chilena de Radiología

Palabras clave: Calidad, Comité editorial, Elsevier. 